\section{La Guía de la OMS/WFME para la acreditación de la formación médica de grado}

Fiel a su compromiso ante la sociedad de promover la calidad de la educación médica, la Word Federation for Medical Education (WFME) acaba de hacer público un documento de consenso sobre la acreditación de la formación médica. En esta ocasión se observa una novedad de especial interés como es la participación en la elaboración del citado documento de la Organización Mundial de la Salud (OMS / WHO) fruto de la "Colaboración estratégica OMS-WFME para la mejora de la educación médica” que se estableció en el 2004.

$\mathrm{Al}$ igual que en anteriores documentos de consenso de la WFME, han participado en su elaboración un número importante de expertos, concretamente 38 , procedentes de los cinco continentes. El documento, cuya versión oficial castellana aparece en el presente número de Educación Médica Internacional, ha sido fruto de un elaborado trabajo de los expertos durante más de dos años y que debe calificarse de meritorio tanto por su concreción, simplicidad y oportunidad. La guía que se presenta establece unos criterios de acreditación que, a pesar de las particularidades de cada país, región o institución, son aplicables en su mayor parte de forma universal.

Al hilo de esta guía de la OMS / WFME, de la que no es necesario glosar su interés intrínseco, es conveniente subrayar algunos conceptos que por obvios pudieran pasar desapercibidos. En el siglo XXI la acreditación de la formación médica no es una cuestión novedosa, ni voluntaria, ni sujeta a discusión. Es un principio establecido por todos los expertos en Educación Médica basándose en un conjunto de factores diversos que van desde la complejidad de los sistemas sanitarios y la formación de sus profesionales, hasta la garantía de calidad de los servicios sanitarios, pasando naturalmente por los procesos de globalización. Frente a este hecho de la necesidad de acreditar la formación médica, la OMS / WFME ofrecen un instrumento flexible que puede ser utilizado por una comunidad concreta (Facultad, Universidad, Región, Comunidad Autónoma, País, Estado o Nación) de forma directa o adaptándolo a la tradición, experiencia o particularidades de dicha comunidad.

Otro aspecto a considerar es la conveniencia de movernos en unas coordenadas comunes. Por ello, los autores de la guía (OMS / WFME) recomiendan y alientan la cooperación internacional y el intercambio de información frente al aislacionismo o, aún peor, frente al interés de desarrollar nuevos métodos y formulas al margen de la mejor evidencia.

\section{WHO/WFME Guidelines for Accreditation of Basic Medical Education}

True to its commitment to promote quality medical education, the World Federation for Medical Education (WFME) has published a consensus document on the accreditation of medical training. This time, thanks to the "WHO-WFME strategic collaboration for the improvement of medical education", in operation since 2004, the document has been drawn up with the participation of the World Health Organization (WHO).

Like previous WFME consensus documents, the preparation and writing involved many experts from all continents (thirty-eight in all). The document appears in this issue of Educación Médica Internacional in its official Spanish version. It is the result of more than two years' work and deserves praise for its conciseness, simplicity and timeliness. It lays down a set of accreditation criteria which can for the most part be applied as they stand in different countries, regions and institutions.

The publication of this WHO/WFME guide gives me the opportunity to reflect on a series of matters which are sometimes taken for granted. The accreditation of medical training is not a new issue, nor is its importance under discussion in the 21st century: given the pressures of globalization, the complexity of the health systems today and the need to guarantee quality in health service provision, accreditation is universally acknowledged by the experts as a vital element of medical education. The WHO/WFME have designed a flexible tool for medical accreditation which can be used by faculties, universities, regions and the Spanish autonomous communities, and indeed by other countries, with only minor modifications.

The establishment of a common framework is particularly important. The WHO/WFME guide promotes international cooperation and information exchange to prevent isolationism and the occasional attempts to develop new methods and formulae that are not supported by the best evidence.

Another key issue is the direct impact any kind of evaluation has on the process evaluated. The implementation of processes of accreditation of medical training is likely to have a significant, positive effect. However, the guidelines must be consistently applied; care must be taken to ensure that they are suited to particular environments and that they can adapt to changing trends. The guidelines can greatly simplify the task of improving the quality of medical training for university authorities and evaluation agencies alike, but we must be aware of the danger of their becoming a bureaucratic instrument that imposes 
Un elemento de extraordinaria relevancia a tener en cuenta es el impacto directo que cualquier tipo de evaluación tiene un sobre el proceso evaluado; por tanto, es de esperar que la implementación de los procesos de acreditación de la formación medica generen un impacto significativo y positivo en la misma. Una aplicación incorrecta de estas directrices, la falta de su adecuación a la realidad concreta de un ámbito determinado, o su aplicación sin una revisión periódica a lo largo del tiempo podrían derivar en un impacto negativo de la formación médica. Nos encontramos frente a un instrumento que puede facilitar en gran medida la responsabilidad de mejorar la calidad de la formación médica tanto de las autoridades universitarias como de las agencias de evaluación, pero que podría convertirse en un instrumento burocrático que homogeneizara y perpetuara los vicios y carencias del sistema.

Dado el respeto que la OMS/WFME tienen por la soberanía nacional, como no podía ser de otra manera, la propia guía califica su contenido de "recomendaciones", es decir guías de cumplimiento no obligado. Por ello, nos parece aún más necesario insistir a los gestores con responsabilidades en el ámbito de la acreditación de la formación médica que sean sensibles a estas recomendaciones de cooperación internacional y que no regateen esfuerzos para intercambiar tanto expertos como información, incluyendo las experiencias en las mejores prácticas, en la implementación de los diferentes modelos y la gestión de los mismos. Tampoco deberían desdeñarse los esfuerzos necesarios para buscar mecanismos de reconocimiento recíproco de los sistemas de acreditación.

Finalmente merece un comentario el espíritu de globalidad que respira el documento de la OMS / WFME. Las tan cacareadas tres fases del continuum educativo (formación básica, formación especializada y desarrollo profesional continuo), quizá serían un verdadero contínuum si estuvieran sometidas a un sistema global y coherente de acreditación. Una gestión de este tipo permitiría una comunicación fluida entre las tres etapas de la formación médica, una harmonización de los requisitos para cada etapa y, por supuesto, un inmejorable sistema del control de calidad de la formación médica. Si bien las agencias acreditadoras pueden parecer en una primera instancia los actores protagonistas de un sistema de acreditación de la formación médica no está por demás recordar que son los instrumentos, y que los verdaderos protagonistas son los recipiendarios, los médicos y sus representantes, las facultades de medicina, las sociedades científicas y los colegios profesionales. Todos juntos, corporativamente, deben organizar y coordinar esfuerzos en favor de un sistema global de acreditación de la formación médica que garantice al ciudadano el mejor profesional posible. an excessive level of standardization and merely perpetuates the problems that the system faces today.

Out of respect for national sovereignty, the WHO/WMFE guide defines its contents as "recommendations"; that is, its application is not compulsory. This is why it is all the more necessary to urge those in charge of the accreditation of medical training to study these recommendations for international cooperation and to do all they can to encourage the exchange of information between experts, incorporating their experience in their practices and in the implementation and management of models. They should also make every effort to find mechanisms that ensure the reciprocal recognition of accreditation systems.

Finally, I would like to stress the global spirit of the WHO/WFME document. The much-discussed three stages of the educational continuum (basic training, specialized training and lifelong learning) has the potential to become a valid model if it has the support of a sound accreditation system. The system described here will promote fluid communication between the three stages in medical training, will help to harmonize the requirements for each stage and, of course, will act as an excellent quality control system in medical training. Though the accrediting agencies may at first sight seem to be the protagonists of the system, the true focus should be on those whose performance is being evaluated: doctors and their representatives, medical schools, scientific societies and professional associations. All these actors should organize themselves collectively and coordinate efforts to create a global system for the accreditation of medical training that will provide society with a steady supply of highly skilled medical experts. 